\title{
Mitogenic Responses of Lymphocytes from Two Lines of Chickens Selected for High and Low Competences in Graft-versus-Host Reaction.
}

\author{
Suguru Mashima, Jin-ichi OkumURA ${ }^{1}$, Ikuo OKada ${ }^{2}$ \\ and Kouzaburoh Y АмАмото ${ }^{1}$ \\ Graduate School of Science and Technology, Niigata University, \\ Niigata 950-21. \\ ${ }^{1}$ Faculty of Agriculture, Niigata University, \\ Niigata 950-21. \\ ${ }^{2}$ Faculty of Applied Biological Science, Hiroshima \\ University, Higashi-Hiroshima 724
}

Two White Leghorn lines, HA and LA, which were developed by selection for high and low competences in graft-versus-host reaction (GVHR) and found to differ in resistance to Marek's disease, were compared for their responses to the mitogenic lectins in vitro. The numbers of peripheral blood lymphocytes were similar in both lines. The HA line showed higher incorporation of ${ }^{3} \mathrm{H}$-thymidine than the LA line, when they were stimulated with Con A and PHA. These results have suggested that the difference in response to the mitogens between the lines is attributed to their lymphoproliferative ability. Based on these findings, the relationship between resistance to MD and lymphoproliferative ability was discussed.

(Jpn. Poult. Sci., 29 : 98-105, 1992)

Key words: Con A, PHA, mitogenic response, graft-versus-host reaction, chickens.

\section{Introduction}

The White Leghorn lines, HA and LA were developed by selection for high and low donor competences in GVHR from the same base population ${ }^{1,2)}$. The HA line also showed high competence in immune response to diphenyl group and bovine serum albumin $^{3)}$. On the contrary, the LA line showed low immune response and showed strong resistance to Marek's disease (MD) compared with the HA line ${ }^{4)}$.

It has been suggested that the resistance to MD correlates with lymphoproliferative ability in chickens ${ }^{5,6}$. So, lymphoproliferative ability was compared between the two lines by measuring response to mitogenic lectins in vitro.

\section{Materials and Methods}

\section{Chickens}

Chickens used in the present study were two White Leghorn lines, HA and LA, which were established by selection for high and low GVHR competences. Both lines have the same genotype at the major histocompatibility B complex (MHC) of chickens. 
A group of ten birds was prepared from both lines and used for each experiment. Culture conditions were determined by using outbred male chickens aged 9 to 11 weeks old.

\section{Mitogenic lectins}

Phytohaemagglutinin-p (PHA-p, L-9132, Lot No. 58F-9408, Sigma Chemical Co., St. Louis, MO, USA) and Concanavalin A (Con A, Lot No. OD 06496, Pharmacia, Tokyo, Japan) were used as mitogen. Optimum dose of mitogen was examined at the range of $5 \mu \mathrm{g} / \mathrm{m} l$ to $100 \mu \mathrm{g} / \mathrm{m} l$ for Con A and $15 \mu \mathrm{g} / \mathrm{m} l$ to $30 \mu \mathrm{g} / \mathrm{m} l$ for PHA-p as final concentration. The culture was performed as described below.

\section{Mitogen culture}

The responsiveness to mitogenic lectins was examined at $3_{-}^{-}, 6-$, and 9 -weeks of age by the method previously described ${ }^{7,8)}$. Briefly, 0.2 or $0.5 \mathrm{ml}$ of blood was collected with heparinized syringe from a wing vein and diluted to $10 \mathrm{ml}$ with RPMI-1640 medium (Sigma Chemical Co.) supplemented with penicillin $(100 \mathrm{IU} / \mathrm{m} l)$ and streptomycin $(100 \mu \mathrm{g} / \mathrm{m} l)$. One $\mathrm{m} l$ of the suspension and $50 \mu l$ of the mitogen solution were dispensed into a culture tube (No. 2058, Falcon, Oxnard, CA, USA). For the control, the same amount of the medium was dispensed instead of mitogen solutions. The culture was conducted at $40^{\circ} \mathrm{C}$ in a $5 \%-\mathrm{CO}_{2}$ atmosphere for $72 \mathrm{hr}$., and pulse-labeling was performed with $18.5 \mathrm{kBq}$ of ${ }^{3} \mathrm{H}$-thymidine (NET-027, $247.9 \mathrm{GBq} / \mathrm{mmol}$, New England Nuclear Boston, MA, USA) during the last $24 \mathrm{hr}$. Each experiment was carried out in triplicate.

\section{Determinations of ${ }^{3} \mathrm{H}$-thymidine incorporation}

The culture tubes were centrifuged at $3000 \mathrm{rpm}(1660 \times \mathrm{g})$ for $20 \mathrm{~min}$. The sediment was washed twice with ice cold $10 \%$ trichloro acetic acid solution. After discarding the supernatant, the sediment was dissolved with $0.5 \mathrm{ml}$ of $10 \%$ sodium lauryl sulfate solution and treated with $100 \mu l$ of $30 \% \mathrm{H}_{2} \mathrm{O}_{2}$ to avoid color quenching. Radio activity was counted with liquid scintillation counter (Aloka, Tokyo, Japan) by using the Aquasol-2 (New England Nuclear) for the scintillation cocktail. Data was expressed as $\Delta \mathrm{cpm}$ and stimulation index (S. I.). Those values were expressed by the formula :

$\Delta \mathrm{cpm}=$ mean $\mathrm{cpm}$ of mitogen stimulating cultures - mean $\mathrm{cpm}$ of control cultures.

Stimulation index (S.I.) $=\frac{\text { mean cpm of mitogen stimulating cultures }}{\text { mean cpm of control cultures }}$

Statistical analysis

Data was evaluated by analysis of variance using the least squares method of HARVEY ${ }^{9}$.

\section{Result}

\section{Optimum culture condition}

Suitable dilution of blood was examined for the culture at $40^{\circ} \mathrm{C}$. The results showed that $1: 50$ of dilution was more effective than $1: 20$ (Fig. 1). Therefore, a dilution $1: 50$ was chosen for the further experimets.

Next, optimum concentrations of the mitogenic lectins were examined and the 


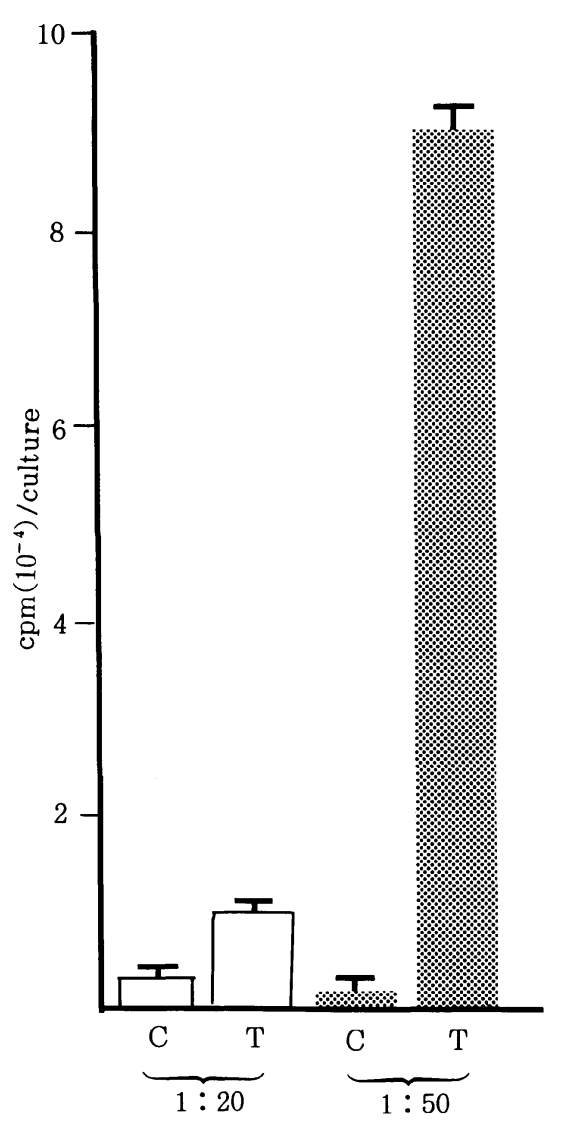

Fig. 1. Effect of different dilutions of blood on incorporation of ${ }^{3} \mathrm{H}$-thimidine. C: control culturs. $\mathrm{T}: 100 \mu \mathrm{g} / \mathrm{ml}$ of PHA treated cultures.

results are shown in Fig. 2. It was found that suitable concentrations was $20 \mu \mathrm{g} / \mathrm{m} l$ for Con A and $25 \mu \mathrm{g} / \mathrm{ml}$ for PHA-p. So, the comparison of mitogenic responses between the lines were conducted at the $1: 50$ dilution of blood and at the concentration of $20 \mu \mathrm{g} / \mathrm{m} l$ for Con A and $25 \mu \mathrm{g} / \mathrm{m} l$ for PHA-p.

Difference in mitogenic responses between the $H A$ and LA lines

As shown in Table 1, $\Delta \mathrm{cpm}$ values of the HA line tended to be higher than those of the LA line for both lectins. Significant differences were observed at 3 and 6 weeks of age for Con A, and at 6-weeks of age for PHA-p.

The differences in stimulation indices (S. I.) between the lines were less clear-cut as compared with $\Delta \mathrm{cpm}$ (Table 2). However, significant differences were obtained at 3 weeks of age for Con A, and at 6 weeks of age for PHA-p. The lower level of significance for the line difference in S.I. as compared with $\Delta \mathrm{cpm}$ was noted to associate with incorporation levels of ${ }^{3} \mathrm{H}$-thymidine in each control culture. Indeed HA line showed higher incorporation levels of ${ }^{3} \mathrm{H}$-thymidine in the control culture than the LA line (Table 3). 

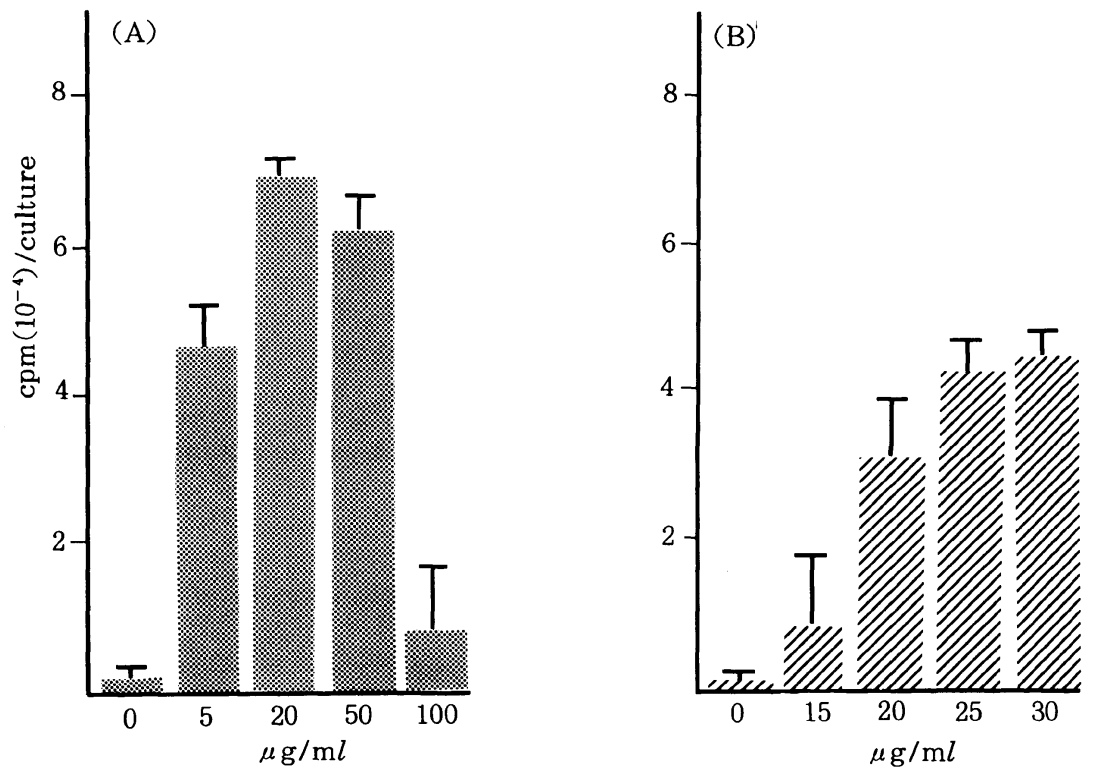

Fig. 2. Dose-response relationship of mitogens and ${ }^{3} \mathrm{H}$-thimidine incorporation by peripheral blood cells of chickens. (A) Con A, (B) PHA-p. Blood was diluted $1: 50$. Other conditions of the experiment are given in Materials and Methods.

Table 1. The comparison of $\Delta \mathrm{cpm}$ between the HA and LA lines in mitogen stimulating cultures

\begin{tabular}{cccrr}
\hline \hline \multirow{2}{*}{ Age (wk) } & line & $\begin{array}{c}\text { No. of } \\
\text { birds }\end{array}$ & \multicolumn{1}{c}{ Mitogen } \\
\cline { 4 - 5 } 3 & H A & 10 & $69,584.0 \pm 9,404.0^{\mathrm{a}}$ & PHA-p \\
\hline \multirow{2}{*}{6} & L A & 10 & $20,759.0 \pm 9,404.0^{\mathrm{b}}$ & $12,808.0 \pm 3,404.0^{\mathrm{a}}$ \\
& H A & 10 & $117,646.5 \pm 11,253.1^{\mathrm{a}}$ & $101,965.7 \pm 11,935.5^{\mathrm{a}}$ \\
& L A & 10 & $45,060.4 \pm 11,253.1^{\mathrm{b}}$ & $36,378.7 \pm 11,935.5^{\mathrm{b}}$ \\
& H A & 10 & $137,306.1 \pm 24,872.9^{\mathrm{a}}$ & $44,365.3 \pm 14,798.9^{\mathrm{a}}$ \\
& L A & 10 & $116,094.8 \pm 24,872.9^{\mathrm{a}}$ & $41,109.1 \pm 14,798.9^{\mathrm{a}}$ \\
\hline
\end{tabular}

${ }^{1)}$ For each group, the means with different superscript within column are significantly different $(\mathrm{P}<0.01)$.

In addition, no significant differences were seen for the numbers of peripheral blood lymphocytes between the lines (Table 4). So it was suggested that the difference in $\Delta \mathrm{cpm}$ between the lines did not depend on the difference in the numbers of peripheral blood lymphocytes.

Fig. $3 \mathrm{~A}-\mathrm{C}$ show the relationship between responses to Con A and PHA-p. Although no clear-cut relation was observed between the responses to both mitogens, obvious line difference was observed. The responses to both lectins at 6 weeks of age formed the separate clusters for each line (Fig. 3 B). 
Table 2. The comparison of stimulation index between the HA and LA lines in mitogen stimulating cultures

\begin{tabular}{ccccc}
\hline \hline \multirow{2}{*}{ Age (wk) } & line & $\begin{array}{c}\text { No. of } \\
\text { birds }\end{array}$ & \multicolumn{2}{c}{ Mitogen } \\
\cline { 4 - 5 } & & 10 & $54,63 \pm 7.39^{\mathrm{a}}{ }^{1)}$ & $11.58 \pm 3.26^{\mathrm{a}}$ \\
\multirow{2}{*}{3} & H A & 10 & $22.07 \pm 7.39^{\mathrm{b}}$ & $12.95 \pm 3.26^{\mathrm{a}}$ \\
& L A & 10 & $101.51 \pm 16.55^{\mathrm{a}}$ & $192.60 \pm 25.88^{\mathrm{a}}$ \\
6 & H A & 10 & $87.18 \pm 16.55^{\mathrm{a}}$ & $32.02 \pm 25.88^{\mathrm{b}}$ \\
9 & L A & 10 & $85.02 \pm 19.13^{\mathrm{a}}$ & $28.25 \pm 10.58^{\mathrm{a}}$ \\
& H A & 10 & $105.00 \pm 19.13^{\mathrm{a}}$ & $41.05 \pm 10.58^{\mathrm{a}}$ \\
\hline
\end{tabular}

${ }^{1)}$ For each group, the means with different superscript within column are significantly different $(\mathrm{P}<0.05)$.

Table 3. Spontaneous uptake of ${ }^{3} \mathrm{H}$-thymidine by blood cells of the HA and LA lines $^{11}$

\begin{tabular}{ccccc}
\hline \hline line & $\begin{array}{c}\text { No. of } \\
\text { birds }\end{array}$ & \multicolumn{3}{c}{ Age in weeks } \\
\cline { 3 - 5 } & 10 & $1,357.3 \pm 101.1^{\mathrm{a}^{2)}}$ & 6 & 9 \\
\hline H A & 10 & $1,274.4 \pm 103.7^{\mathrm{c}}$ & $1,761.3 \pm 181.5^{\mathrm{a}}$ \\
L A & 10 & $992.4 \pm 101.1^{\mathrm{b}}$ & $667.6 \pm 103.7^{\mathrm{d}}$ & $1,250.7 \pm 181.5^{\mathrm{a}}$ \\
\hline
\end{tabular}

${ }^{1)}$ Expressed with cpm.

${ }^{2)}$ Means with different superscript within a column are significantly different ${ }^{\mathrm{a}, \mathrm{b}} \mathrm{P}<$ $\left.0.05,{ }^{\mathrm{c}, \mathrm{d}} \mathrm{P}<0.01\right)$.

Table 4. The comparison of lymphocyte numbers in peripheral blood between the $\mathrm{HA}$ and LA lines ${ }^{1)}$

\begin{tabular}{ccccc}
\hline \hline \multirow{2}{*}{ line } & $\begin{array}{c}\text { No. of } \\
\text { birds }\end{array}$ & 3 & 6 & 9 \\
\cline { 3 - 5 } & 10 & $19,700 \pm 924^{\mathrm{a}}{ }^{\mathrm{a}}$ & $21,600 \pm 707^{\mathrm{a}}$ & $21,100 \pm 1,141^{\mathrm{a}}$ \\
H A & 10 & $19,800 \pm 924^{\mathrm{a}}$ & $22,200 \pm 707^{\mathrm{a}}$ & $21,800 \pm 1,141^{\mathrm{a}}$ \\
\hline
\end{tabular}

${ }^{1)}$ Lymphocytes numbers in $1 \mu l$ of peripheral blood.

${ }^{2)}$ Means with different superscript within a column are significantly different $(\mathrm{P}<0.05)$.

\section{Discussion}

Many investigators performed culture of chicken lymphocytes at the temperature $40^{\circ} \mathrm{C}^{10-12)}$. We followed that condition. Previously, LAssila et al. stated that a dilution 1:50 was optimum for the whole blood culture system ${ }^{8)}$. Contrary to this, KoNDo and his colleagues diluted whole blood at $1: 20$ and cultured at the temperature $37^{\circ} \mathrm{C}^{7)}$. The result from present study supported the report of LAssila and his colleagues $^{8)}$. So, it is considered that $1: 50$ of blood dilution is suitable for culturing at $40^{\circ} \mathrm{C}$.

Mitogenic responses to Con $\mathrm{A}$ and PHA are specific for $\mathrm{T}$ lymphocytes in 


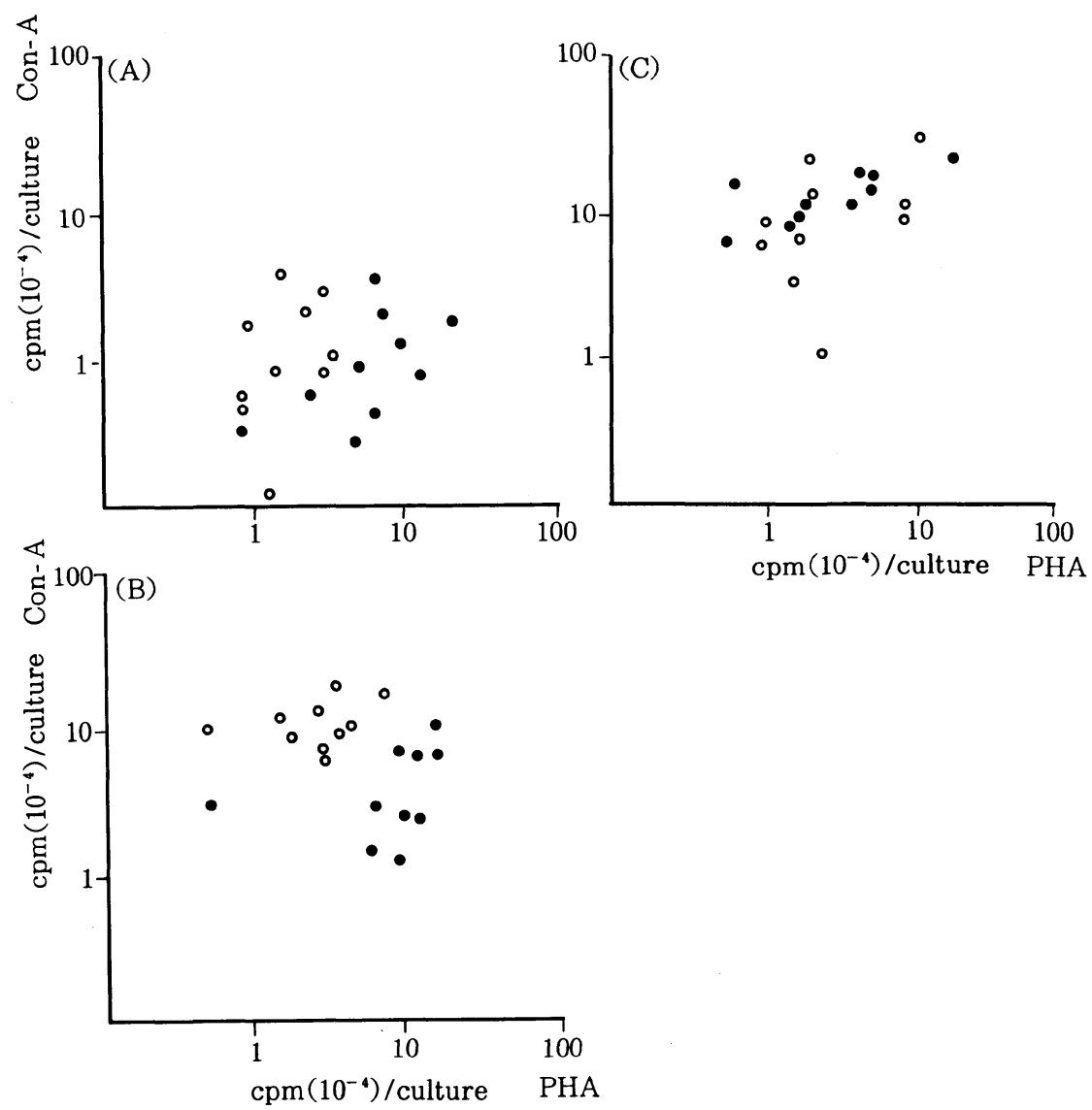

Fig. 3. Relationship between mitogenic responses to Con A and PHA-p (cpm). Open circles and closed circles represent the individuals from the HA and LA line of chickens, respectively, at the age of (A):3-wk., (B) :6-wk. and (C) : 9-wk. The remainder of legend is the same as in Fig. 2.

chickens $^{13,14)}$. Con A stimulation was shown to be under the control of MHC ${ }^{15)}$. The PHA response is also under genetic control ${ }^{16)}$. The present study suggested that responses to these lectins are also under genetic control but the gene(s) are not linked to MHC, since both HA and LA line have same genotype for the MHC complex ${ }^{1)}$.

The high responder to Con A was not always a high responder to PHA-p (Fig. 3 $A-C)$. The spectra of $T$ lymphocytes subset may be different in the responses to Con $\mathrm{A}$ and PHA-p. Hougarth and McKenzie stated that Con A reactive $\mathrm{T}$ cells and PHA reactive $T$ cells were distinguished with the surface antigen $L y-7$ in mice ${ }^{17}$. Such antigen determinants may also exist in $\mathrm{T}$ lymphocytes of chickens.

The birds from the HA line showed a strong response to both lectins as compared with the LA line. Con A and PHA-p stimulate T lymphocytes, but do not activate $\mathrm{B}$ lymphocytes ${ }^{13,14)}$. So, it is considered that the HA line is higher than the LA line in their competences of either proliferation of $\mathrm{T}$ cells or the cooperative eff ect of antigen presentation cells to $\mathrm{T}$ lymphoytes or both. This phenomenon agreed with in vivo 
response of GVHR ${ }^{1,18)}$. Since GVHR is thought to be a $\mathrm{T}$ lymphocyte dependent function $^{19,20)}$, the line differences in mitogenic responses to Con A and PHA-p may also reflect the differences in responses of $\mathrm{T}$ lymphocytes in vivo.

Previous investigations clearly demonstrated that resistance to MD is strongly affected by MHC haplotype ${ }^{21,22)}$. And it has also been suggested that resitance to MD is associated with lymphoproliferative ability ${ }^{5,6}$. In addition, difference in resistance to MD between MHC compatible inbred lines of chickens, RPRL $6_{3}$ and $7_{2}$ was also indicative of the association with lymphoproliferative ability ${ }^{14}$. Present investigation agrees with the observation of FrEDERICKSEN and Gilmour ${ }^{14)}$ and emphasizes the relationship between lymphoproliferative ability and resistance to MD. The interline difference in resistance to MD between $\mathrm{HA}$ and $\mathrm{LA}^{4)}$ is thought to be caused by the difference in lymphoproliferative ability of these lines.

\section{References}

1) Okada, I and H. Mikami (1974) Three generations of selection for high and low donor competences of splenomegaly in chickens. Br. Poult. Sci., 15 : 1-10.

2) OKADA, I. (1982) Interaction of $B$ locus and GVHR-selected lines in the graft-versushost reaction in chickens. Anim. Blood Group. Biochem. Genet., 13 : 273-278.

3) Yanagimoto, T. and I. Okada (1980) Evidence for major histocompatibility linked and non-linked genetic regulation of immune response in chickens. Jpn. J. Zootech. Sci., $51: 127-134$.

4) OкADA, I. and Y. Yамамото (1987) Immunocompetences and Marek's disease resistance in three pairs of chicken lines selected for different immunological characters. Poult. Sci., 66 : 769-773.

5) Pazderka, F., B.M. Longenecker, G.R.J. Law, H.A. Stone and R.F. Ruth (1975) Histocompatibility of chicken populations selected for resistance to Marek's disease. Immunogenet., $2: 93-100$.

6) LeE, F.L. and L.D. BACON (1983) Ontogeny and line differences in the mitogenic response of chicken lymphocytes. Poult. Sci., 62 : 579-584.

7) Kondo, Y., Y. Taniguchi, Y. Sakoe and A. Abe (1988) Effect of starvation on humoral and cell-mediated immune responses. Jpn. Poult. Sci., $25: 330-336$. in Jananese.

8) Lassila, O., J. Eskola and P. Toivanen (1976) A micro method for stimulation of chicken lymphocytes in vitro using whole blood. Clin. Exp. Immunol., 26 : 641-646.

9) Harvey, W.R. (1960) In: Least-squares analysis of data with unequal subclass number. pp. 1-91. Agricultural Research Service. USDA. OH.

10) Vainio, O. and M.J.H. RAtcliffe (1984) Proliferation of chicken peripheral blood leukocytes in response to Pokeweed mitogen is macrophage dependent. Cell. Immunol., 85 : 235-243.

11) Hála, K., K. Schauenstein, K. Neu, G. Kromer, H. Wolf, B. Bock and G. Wick (1986) A monoclonal antibodies reacting with a membrane determinant expressed on activated chicken T lymphocytes. Eur. J. Immunol., 16 : 1331-1336.

12) Knudtson, K.L., M.G. Kaiser and S.J. Lamont (1990) Genetic control of Interleukine-2-like activity is distinct from that of mitogen response in chickens. Poult. Sci., 69 : $65-71$.

13) WeBER, W.T. (1970) Mixed lymphocytes interaction and PHA response of chicken spleen cells in a chemically defined medium. J. Reticuloendoth. Soc., $8: 37-54$.

14) Fredericksen, T.L. and D.G. Gilmour (1983) Ontogeny of Con A and PHA responses of chicken blood cells in MHC-compatible lines $6_{3}$ and $7_{2}$. J. Immunol., 130 : 2528-2533.

15) Miggiano, V., M.Nouth, A. Buder and J.R.L. Pink (1976) Genetic control of the 
response of chicken leukocytes to T-cell mitogen. Nature, 263:61-63.

16) Lassila, O., T. Nurmi and J. Eskola (1979) Genetic differences in the mitogenic responses of peripheral blood lymphocytes in the chicken. J. Immunogenet., 6 : $37-43$.

17) Hougarth, P.M. and I.F.C. McKenzie (1984) lymphocyte antigen. In : Fundamental Immunology (PaUL, W.E., ed.) pp. 457-477. Raven Press, New York.

18) Okada, I., Y.Yамамото and M. Mizuyama (1987) Parabiosis between avian embryos selected for high and low competences of the graft-versus-host reaction. Poult. Sci., 66 : 1090-1094.

19) Hála, K., R.L. Boyd, H. Wolf, G. Bock and G. Wick (1984) Functional analysis of B-L (Ia-like) antigen-bearing chicken peripheral blood cells. Scand. J. Immunol., $20: 15-19$.

20) Wick, G., K. Hála, H. Wolf, R.L. Boyd and K. Schauenstein (1984) Distribution and functional analysis of $\mathrm{B}-\mathrm{L} / \mathrm{Ia}$ antigens on thyroid epithelial cells in spontaneous autoimmune thyroiditis. Mol. Immunol., 21 : 1259-1265.

21) Briles, W.E., R.W. Briles, R.E. Taffts and H.A. Stone (1983) Resistance to malignant lymphoma in chickens is mapped to subregion of major histocompatibility $(B)$ complex. Science, 219 : 977-979.

22) Schierman, L.W and W.M. Collins (1987) Influence of the major histocompatibility complex on Tumor regression and immunity in chickens. Poultry. Sci., $66: 812-818$.

\title{
移植片対宿主反応によって二方向選抜された HA および LA 鶏における $\mathrm{T}$ リンパ球の増殖能について
}

\author{
真島 傑 $・$ 奥村仁一 ${ }^{1} \cdot$ 岡田育穂 ${ }^{2} \cdot$ 山本興三郎 ${ }^{1}$ \\ 新潟大学自然科学研究科 新潟市 950-21 \\ ${ }^{1}$ 新潟大学農学部，新潟市 $950-21$ \\ ${ }^{2}$ 広島大学生物生産学部 東広島市 721
}

HA 系統之 LA 系統の鶏は移植片対宿主反応におけ る脾腫能力の違いによって選抜され，マレック病に対し て異なっだ抵抗性を示すことが知られている。本実験で は，3，6，9 週齢時における $\mathrm{T}$ リンパ球のマイトージ ェンに対する反応性を両系統間で比較した。

両系統間の值を $\Delta \mathrm{cpm}$ で示すと, Con A と PHA のいずれのマイトージェンを用いても，HA 系統で LA 系統よりも高い值が示された。特に 6 週齢では, Con A を用いた際，LA 系統の平均値が $45060.43 \pm$ 11253. 08 であったのに対して，HA 系統は 117646.54 土11253.08 と 2 倍以上も高い值を示した。また刺激指 数は 3,6 週齢で HA 系統が高く, 9 週路で LA 系統 が高い傾向にあった。しかしながら，有意な差が認めら れたのは, Con A を用いた際の 3 週齢と PHA を用い
た際の 6 週齢だけであった。マイトージェンで刺激を加 えない培養においても，HA 系統は LA 系統に比へ， ${ }^{3} \mathrm{H}-$ チ ミジの取り込みが高く, 3 および 6 週路で有意 な差が認められた。また，末梢血中に含まれていたリン パ球の数は LA 系統で高い傾向にあったが，いずれの 週軨であ有意な差が認められなかった。以上の結果より， 両系統間で示されるマイトージェンに対する反応性の違 いは, リンパ球の増殖能の違いによってもたらされてい るものと推察された。そしてさらに，マレック病に対す る抵抗性とリンパ球の増殖能の関連について考察が行な われた。

（家禽会誌, $29 ：$ 98 105, 1992)

キーワード: Con A, PHA, マイトージェン反応, 移 殖片対宿主反応 